\title{
Monitoring and evaluation of seasonal snow cover in Kashmir valley using remote sensing, GIS and ancillary data
}

\author{
H S Negi*, N K Thakur, Rajeev Kumar and Manoj Kumar \\ Snow and Avalanche Study Establishment, Him Parisar, Sector-37A, Chandigarh 160 036, India. \\ *e-mail: negi_hs@yahoo.com
}

\begin{abstract}
Seasonal snow cover is a vital natural resource in the Himalaya. Monitoring of the areal extent of seasonal snow cover is important for both climatological studies as well as hydrological applications. In the present paper, snow cover monitoring was carried out to evaluate the region-wise accumulation and ablation pattern of snow cover in Pir Panjal and Shamshawari ranges of Kashmir valley. The study was carried out for the winter period between November and April of 2004-05, 2005-06 and 2006-07, using multi-temporal WiFS sensor data of IRS-1C/1D satellites. The study shows reduction in the areal extent of seasonal snow cover and rising trend of maximum temperature in three winters for the entire Kashmir valley. This has been validated with 20 years (198889 to 2007-08) climatic conditions prevailed in both ranges of Kashmir valley. Region-wise study shows the spatial and temporal variability in seasonal snow cover within Kashmir valley. Advance melting was observed in Banihal and Naugam/Tangdhar regions than Gurez and Machhal regions. Different geographical parameters of these regions were studied to evaluate the influence on snow cover and it was observed that altitude and position of region with respect to mountain range are the deciding factors for retaining the seasonal snow cover for longer duration. Such region-wise study of snow cover monitoring, can provide vital inputs for planning the hydropower projects, development in habitat areas, recreational and strategic planning in the region.
\end{abstract}

\section{Introduction}

Large areas in Himalaya are covered with seasonal snow cover during winter and snow cover changes significantly due to melting in summer. It has various socio-economic and environmental implications such as: winter tourism, transport, environment, land management, water and many other developmental activities. The knowledge of snow cover distribution throughout the watershed or basin area of interest is also essential for the effective use of snowmelt runoff models (Rango and Martinec 1995; Rango 1996; Singh et al 2000; Kulkarni et al 2002a); therefore monitoring and evaluation of seasonal snow cover is essential and requires a continuous surveillance.
The monitoring of snow cover over rugged mountainous terrain for planning and management of the above activities using ground-based conventional techniques such as manned snow observation stations, physical mapping and monitoring provides limited area information, time consuming and difficult. Satellite remote sensing has proven as a useful tool for snow cover monitoring of vast, rugged and remote areas such as Himalaya in real-time and year-round (Konig et al 2001). Globally, satellite remote sensing has been extensively used for snow cover monitoring (Dozier et al 1981; Dozier 1984, 1989; Hall et al 1995, 1998, 2001, 2002; Negi et al 2008). The medium spatial resolution $(10-90 \mathrm{~m})$ satellite sensors, e.g., Landsat MSS $(80 \mathrm{~m})$ and TM $(30 \mathrm{~m})$, Terra ASTER

Keywords. Snow cover monitoring; accumulation; ablation; WiFS; GIS. 


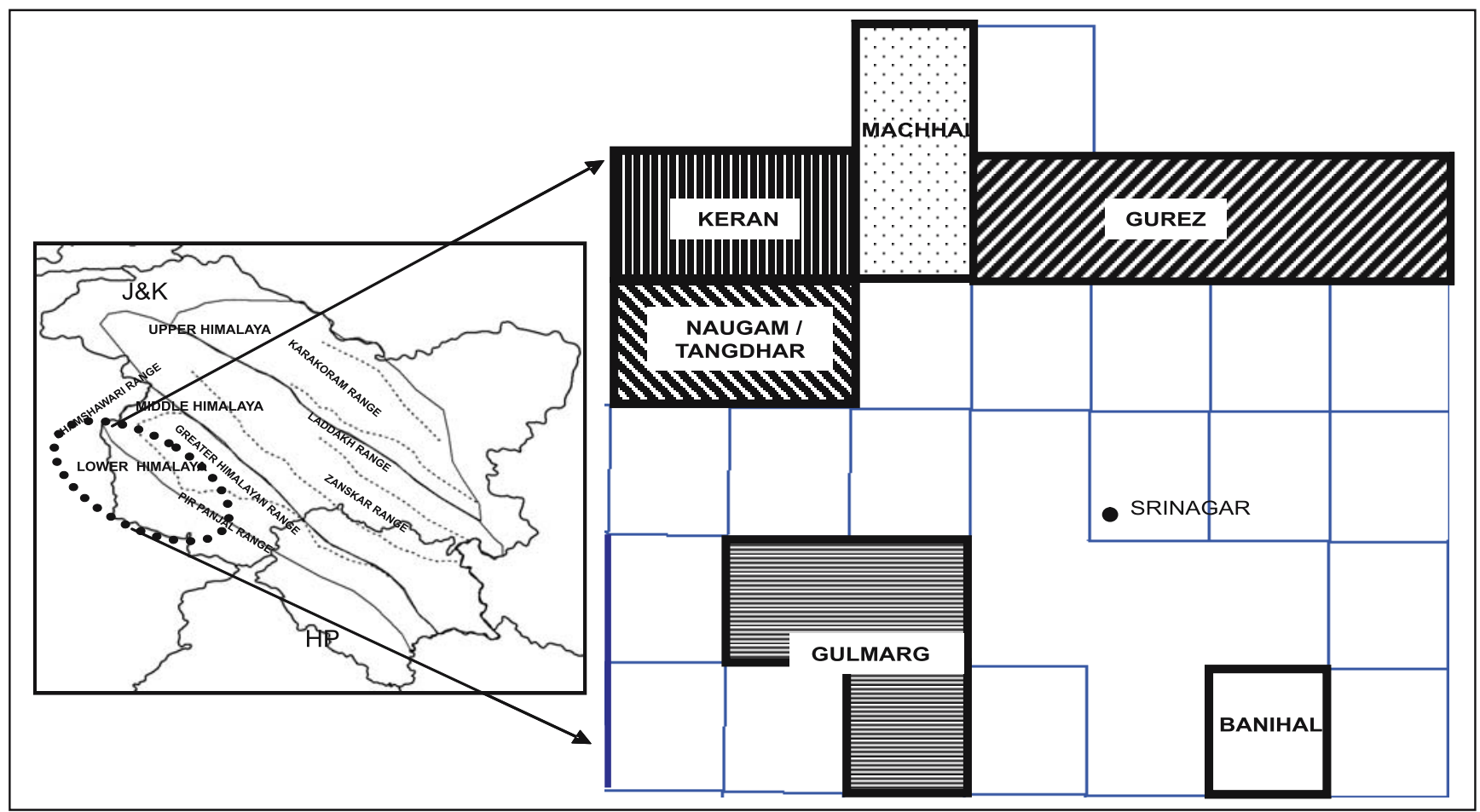

Figure 1. Study area showing all the six regions of Pir Panjal and Shamshawari Ranges, in Kashmir valley (J\&K).

(15-90 m) and Indian Remote Sensing (IRS) LISS-III $(23.5 \mathrm{~m}), \operatorname{WiFS}(188 \mathrm{~m})$, AWiFS $(56 \mathrm{~m})$ have been used for the measurement of snow cover of region/basin specific (Kulkarni et al 2002b, 2003; Kulkarni and Rathore 2006; Gupta et al 2005; Negi et al 2005a, 2009). The distribution of snow cover can be mapped using high reflectance of snow in visible region ( 0.4 to $0.8 \mu \mathrm{m})$ of electromagnetic spectrum and generally, the reflectance of snow is high up to red end of the visible spectrum and it tends to decline in near infrared until $1090 \mathrm{~nm}$ (O'Brien and Munis 1975; Wiscombe and Warren 1980; Warren 1982). However, some time presence of cloud cover can affect delineation of snow cover, due to similar reflectance characteristics of snow and cloud in visible region. Snow and cloud can be discriminated using various techniques such as SWIR band reflectance (Dozier 1985; Racoviteanu et al 2008), textural analysis, association with shadow and multi-temporal satellite data analysis (Kulkarni and Rathore 2003).

Generally with the advent of winter the snowline gradually descends along the slope and ablation during summer results in upward movement of the snowline. Such remarks are made to suggest that in the Himalaya, the snowline may be expected to follow elevation contours. Even the elevation effect is predominant in the Himalaya, making the snowline to follow elevation contours, but there may be many local departures due to influence of vegetation, slope, aspect and positions of the different regions. The snowfall and temperatures vary significantly with altitude, and steep slopes tend to sluff frequently due to more stress on snow cover. The aspect influences incoming radiation, which determines snow cover temperature and strength. Northern hemisphere's winters tend to have more sunshine, and warmer temperatures in southern slopes than northern slopes, which causes advance or late snow melting. Forest cover also influence radiation transfer and moderating the snow surface temperature; this can also affect the snow melting (Mcclung and Schaerer 2006).

Hence, the present study has been carried out to monitor seasonal snow cover in various regions of Pir Panjal and Shamshawari ranges in Kashmir valley using IRS-1C/1D WiFS imageries, GIS and ancillary data. The departures due to local effects (i.e., geographical variables) on snow cover were also studied.

\section{Study area and data used}

Pir Panjal and Shamshawari ranges of Kashmir valley in J\&K (India) has been selected as the study area which consists of six regions (Banihal, Gulmarg, Naugam/Tangdhar, Keran, Machhal and Gurez). The study area lies between $73^{\circ} 45^{\prime} 00^{\prime \prime}$ to $75^{\circ} 30^{\prime} 00^{\prime \prime} \mathrm{E}$ longitude and $33^{\circ} 30^{\prime} 00^{\prime \prime}$ to $35^{\circ} 00^{\prime} 00^{\prime \prime} \mathrm{N}$ latitude. The total area is approximately $8980 \mathrm{~km}^{2}$ and covers 14 Survey of India (SoI) map sheets of 


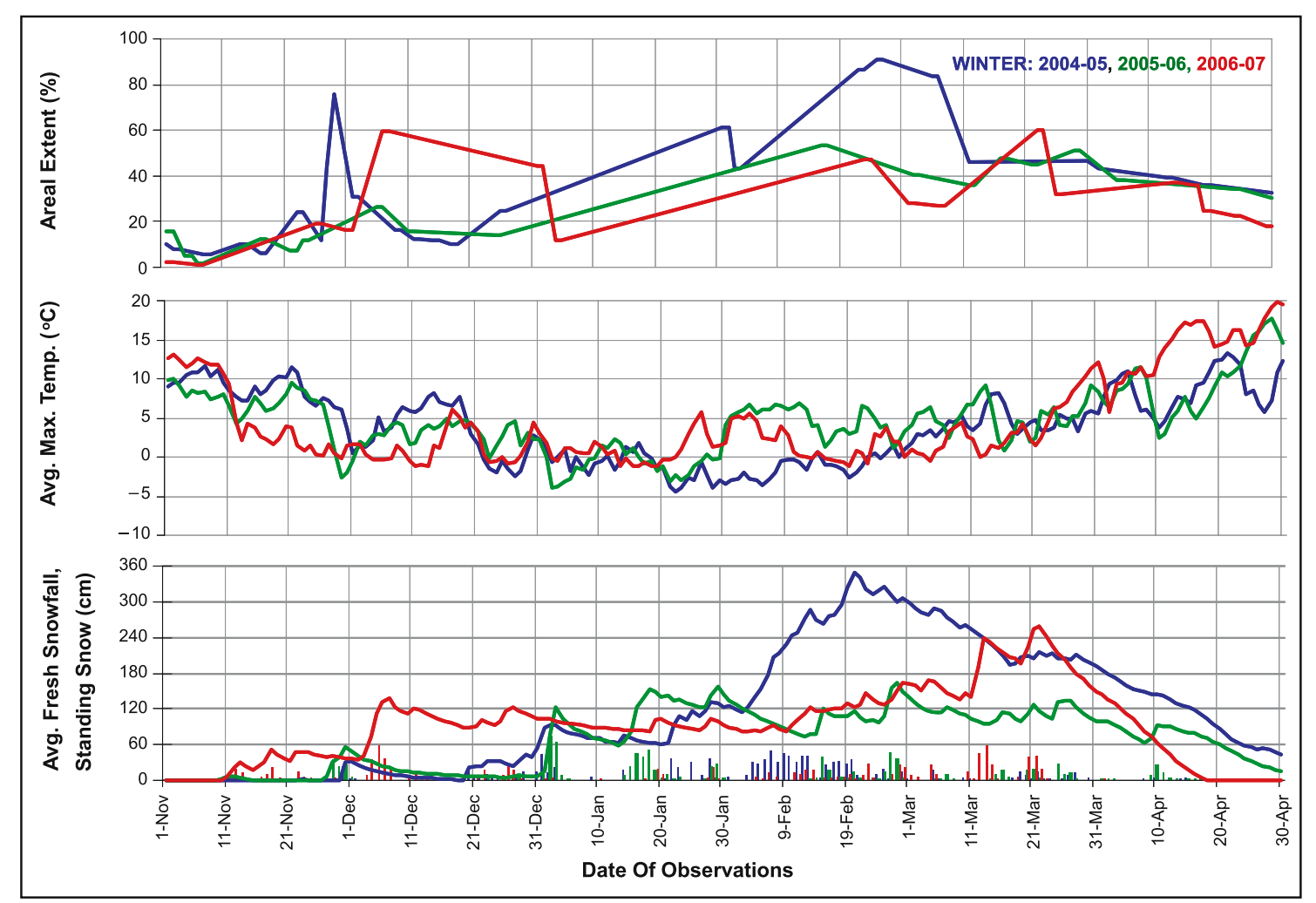

Figure 2. Estimated areal extent of seasonal snow cover and ground observed average maximum temperature, fresh snowfall and standing snow of different years in Kashmir valley.

1:50,000 scale (figure 1). Generally the altitude of the study area varies from $1800 \mathrm{~m}$ to $4000 \mathrm{~m}$ and lies in the lower Himalayan snow climatic zone, categorized as high solid precipitation, short winter periods and warm temperature zone (Sharma and Ganju 2000). Generally, lower Himalayan region has short monsoon period, i.e., July-August (Bahadur 1993; Singh and Kumar 1997). This lower Himalayan snow climatic zone is adjacent to greater Himalayan snow climatic zone which is characterized by fairly cold temperatures, heavy snowfall and higher elevations.

In the present study, Wide Field Sensor (WiFS) of IRS-1C/1D satellites has been used for the monitoring of areal extent of snow cover because near-real time satellite data was available to us from DEAL (DRDO) laboratory, Dehradun. WiFS sensor has $188 \mathrm{~m}$ spatial and five days temporal resolution, with the swath of $810 \mathrm{~km}$. This sensor has two spectral bands, one in visible $(0.62-0.68 \mu \mathrm{m})$ and another in near infrared $(0.77-$ $0.86 \mu \mathrm{m})$ wavelength region. In this investigation, total 60 multi-temporal satellite imageries were analyzed for the period between November and April of 2004-05 to 2006-07.

The field collected snow-meteorological data, e.g., fresh snowfall, snowfall days, standing snow and maximum temperature recorded at various observatories located in different regions were used for the ground validation. A DEM of the study area, generated using contours and spot heights of 1:50,000 scale map sheets was used for geographical analysis.

\section{Methodology}

The pre-processing of WiFS satellite data was carried out in ERDAS Imagine software and satellite data was geo-referenced up to sub-pixel accuracy using ground control points such as bends, junctions of rivers/nallahs, etc. Initially co-ordinates of GCP were measured using Survey of India (SoI) maps of 1:50,000 scale and later on, image to image registration was carried out for the time series analysis. The region-wise snow cover maps were generated and areal extent of snow cover was estimated using hybrid (visual i.e., manual digitization and unsupervised classification) technique (Kulkarni et al 2002a; Kulkarni and Rathore 2003; Negi et al 2005b). This hybrid technique was necessary because long mountain shadow in the months of November to February normally make it difficult to use only classification technique for snow cover delineation. Therefore all shadows above snowline were considered as snow covered areas. March 


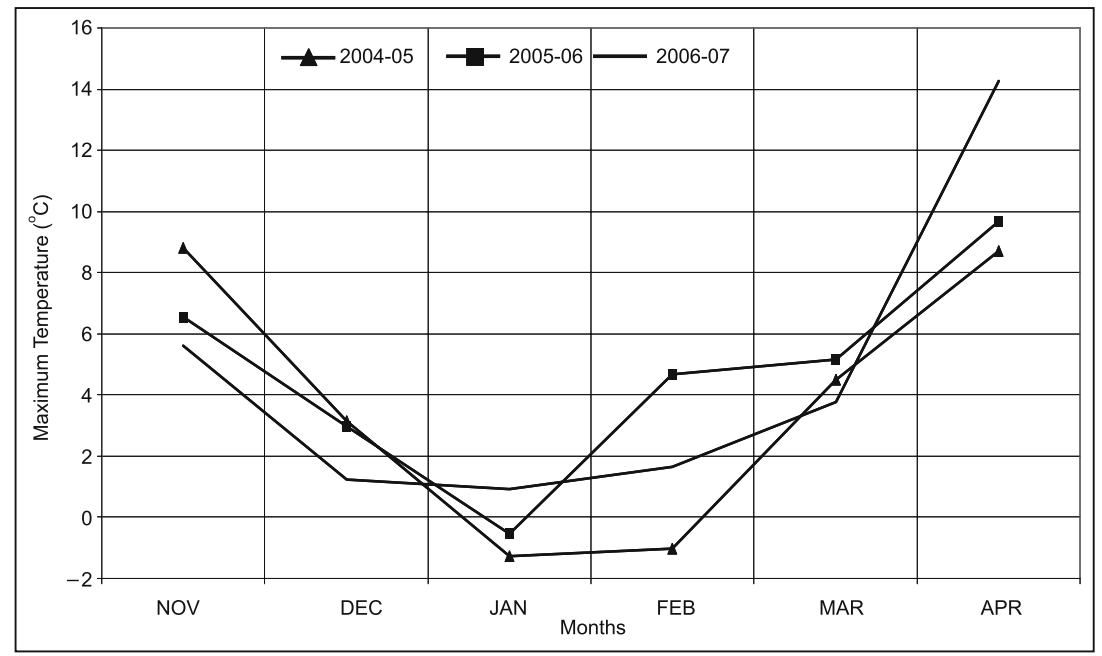

Figure 3. Month-wise average maximum temperature pattern in Kashmir valley.

onwards generally mountain shadows were negligible hence, unsupervised classification technique was used. In this study, snow and cloud has been discriminated using textural analysis; where the snow shows texture of mountainous pattern but this can not be observed when area is covered by cloud. Kulkarni et al (2004) have also used this technique to map snow cover in Baspa and Satluj basins of western Himalaya.

The GIS layer of map boundaries of fourteen map sheets was generated to estimate region-wise areal extent of snow cover. The R2V software was used to digitize the contours and spot height from 1:50,000 SoI map sheets and further ERDAS Imagine software was used for surface (DEM) generation. The nonlinear TIN interpolation method, which uses a fifth-order polynomial, was used for the smooth surface DEM at $6 \mathrm{~m}$ spatial resolution (Leica Geosystems 2006). Terrain parameters such as slope, aspect, and elevation were generated using DEM and forest cover was estimated from satellite data using NDVI technique for different regions. The geographical analysis based on the terrain parameters and positions of the regions were carried out in detail for each region. Daily ground data (i.e., maximum temperature, fresh snowfall amount and snowfall days of different regions) observed at point observatories locations of Snow and Avalanche Study Establishment (SASE) were analyzed for comparison/validation at daily, monthly basis and region-wise.

\section{Results and discussions}

\subsection{Snow cover monitoring in Kashmir valley}

The study shows that snow cover undergoes number of variations during the winter period in
Table 1. Month-wise average and total snowfall (cm) in Kashmir valley.

\begin{tabular}{lccc}
\hline & \multicolumn{3}{c}{ Year } \\
\cline { 2 - 4 } Month & $2004-05$ & $2005-06$ & $2006-07$ \\
\hline November & 26 & 98 & 115 \\
December & 96 & 17 & 244 \\
January & 250 & 432 & 70 \\
February & 585 & 207 & 221 \\
March & 107 & 149 & 308 \\
April & 18 & 65 & 03 \\
Total & 1082 & 968 & 961 \\
\hline
\end{tabular}

Kashmir valley (figure 2). November-December shows generally 10-20\% extent of seasonal snow cover except one odd case, whereas $40-90 \%$ snow covered area was observed in January-February and thereafter it starts depleting. Based on these variations, winter period can be further categorized into three parts as: early winter (NovemberDecember), mid winter (January-February) and late winter (March-April). Maximum (90\%) areal extent of snow cover was observed in 2004-05, whereas it was $50-60 \%$ in winters $2005-06$ and 2006-07. This indicates overall reduction in seasonal snow cover from winter 2004-05 to 2006-07.

In Kashmir valley, the average of the maximum temperature recorded at various observatories lies above $0^{\circ} \mathrm{C}$ in November-December for all winters and it remains below $0^{\circ} \mathrm{C}$ in January-February except for 2005-06 and 2006-07 winters, where it suddenly rises in the last week of January. Further, March onwards for all winters the maximum temperature remains above $0^{\circ} \mathrm{C}$ (figure 2). The rising trend in monthly maximum temperature was observed from winter 2004-05 to 2006-07 (figure 3). It was more than $0^{\circ} \mathrm{C}$ throughout all 


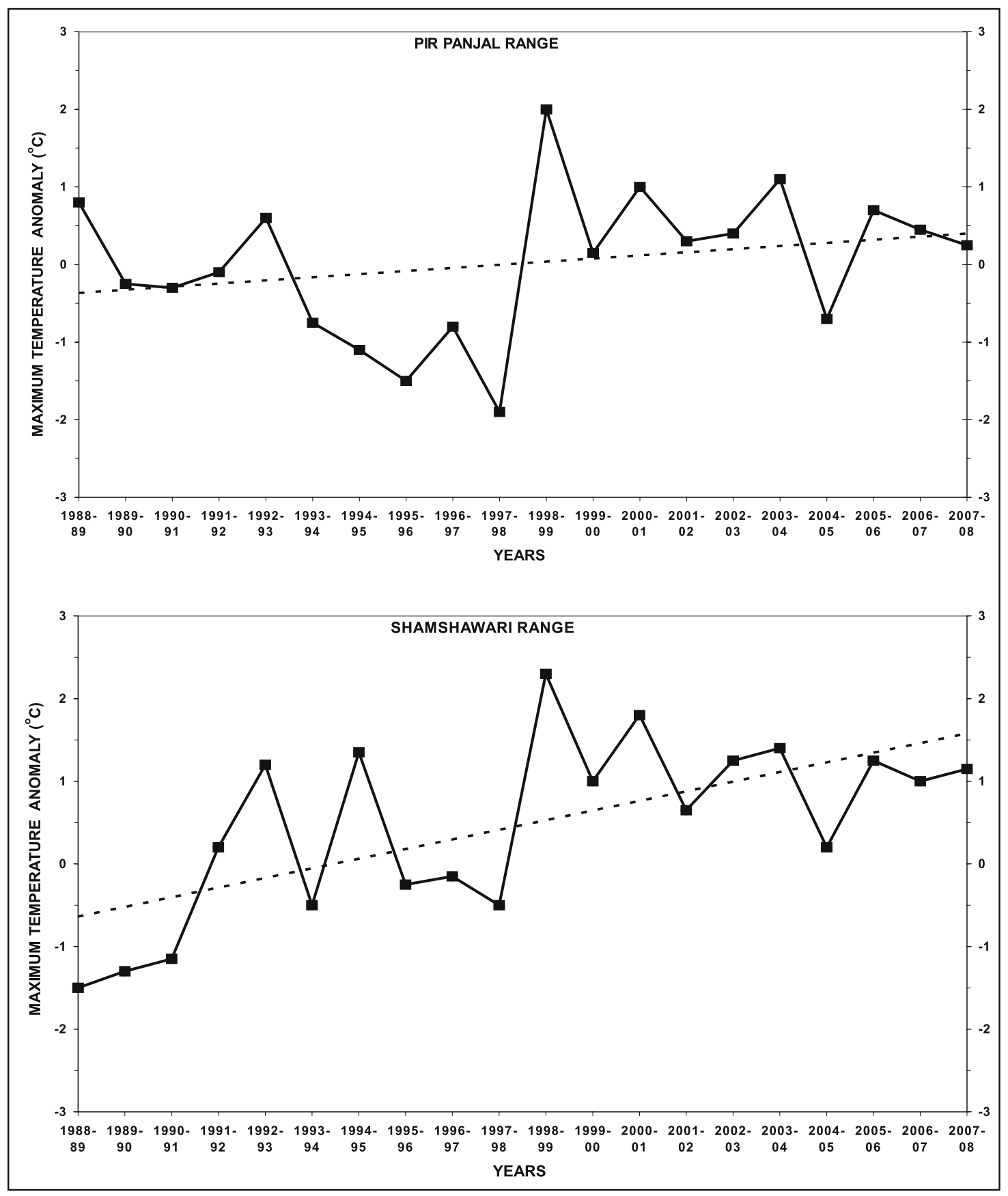

Figure 4(a). Trends in maximum temperature over different ranges in Kashmir valley (source: Shekhar et al 2009).

the winters except January-February of 2004-05 and January of 2005-06, where it was subzero. The amount of total snowfall observed in 200405 winter was $1082 \mathrm{~cm}$, whereas it was $968 \mathrm{~cm}$ and $961 \mathrm{~cm}$ in winters 2005-06 and 2006-07, respectively (table 1 ).

This decreasing trend in areal extent of snow cover, rise in maximum temperature and decreasing trend in total snowfall may be the indicators of global warming or climate change. As the same trend of rise in maximum temperature and reduction in snowfall were observed by Shekhar et al
(2009) for 20 years (1988-89 to 2007-08) in Pir Panjal and Shamshawari ranges of Kashmir valley using field observatories data (figure 4a, b).

\subsection{Region-wise snow cover monitoring}

The region-wise areal extent of snow cover also indicates, more snow accumulation and delayed snow melting in Gurez and Machhal region than other regions of Kashmir valley (figure 5). The other regions have generally same accumulation pattern, however, advance snow melt observed 


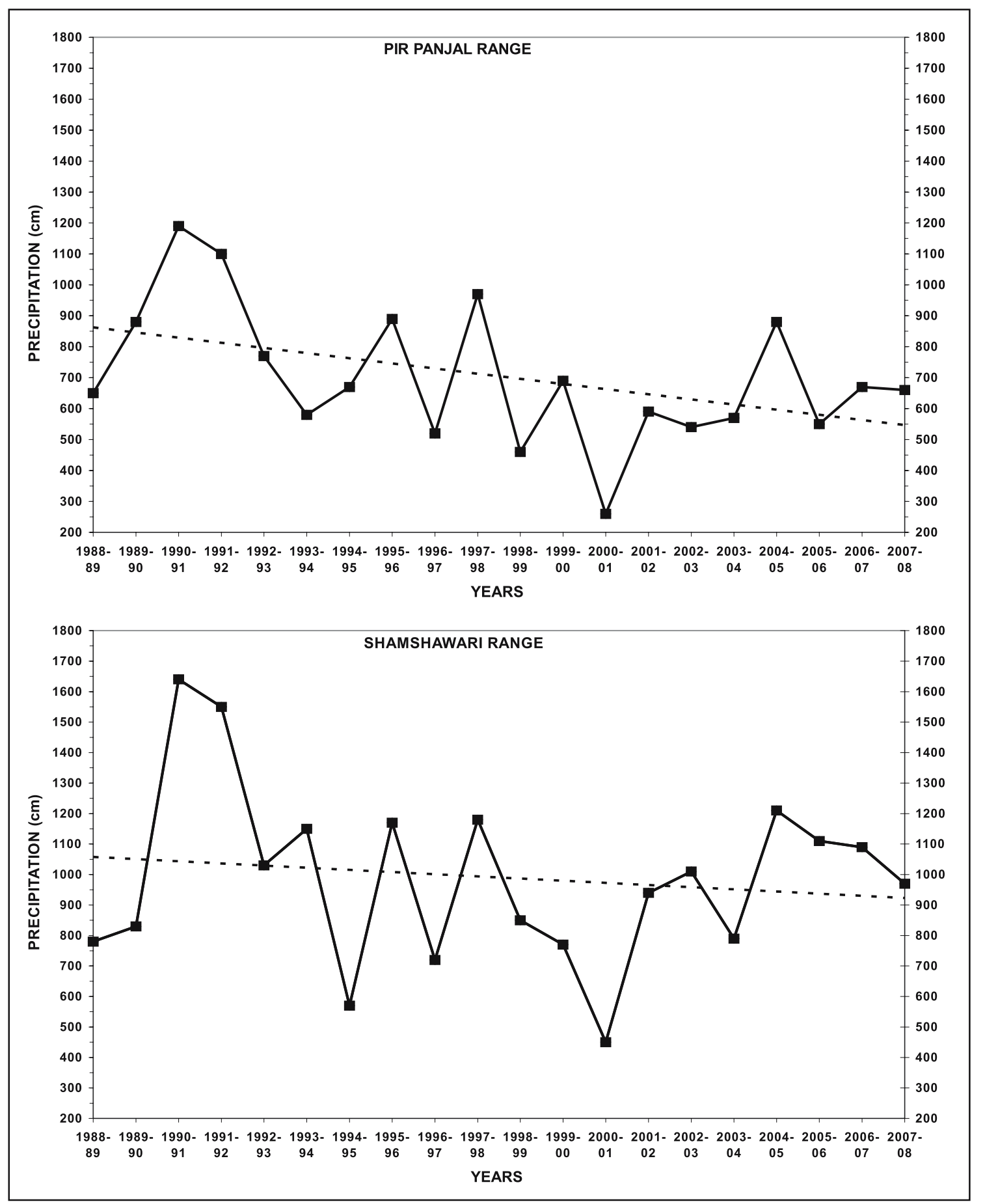

Figure 4(b). Total seasonal precipitation over different ranges in Kashmir valley (source: Shekhar et al 2009).

in Banihal and Naugam/Tangdhar regions than Gulmarg and Keran regions. Further, March onwards the considerable melting has been observed in all regions.

Field observatories data also shows that Gurez and Machhal regions receive low temperature, and more snowfall than any other regions (figure 6). Temperature pattern is generally same for other regions during winter and snowfall pattern is similar till March, except for Banihal region, where slightly less snowfall was observed. In the month of April, insignificant snowfall observed in Banihal, Gulmarg and Naugam/Tangdhar regions; however, considerable amount of snowfall observed in Keran, Machhal and Gurez regions. More number of snowfall days were observed in Gurez and Machhal regions than other regions, whereas less number of snowfall days and advance melting was observed in Banihal region (table 2). 


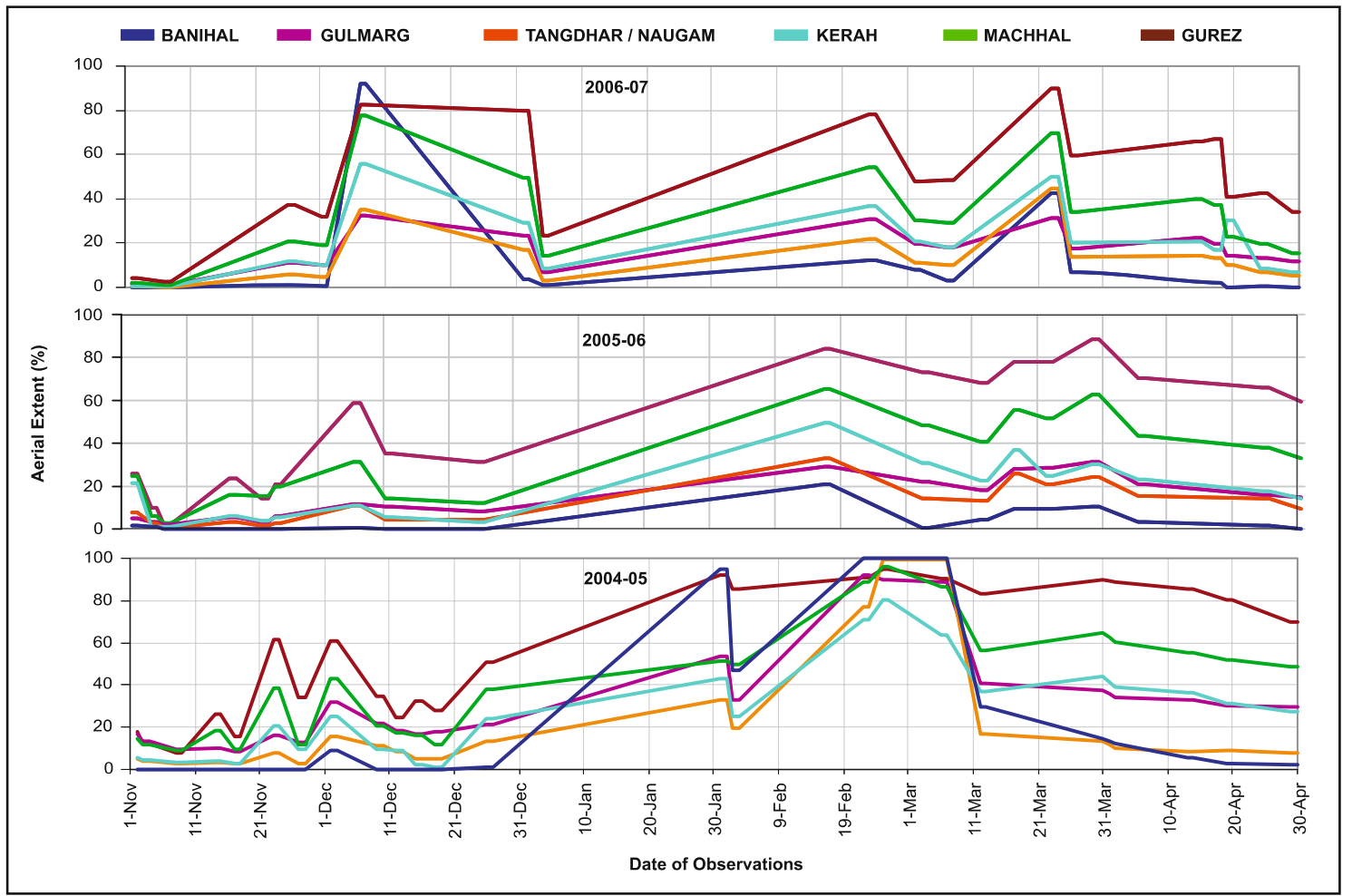

Figure 5. Region-wise accumulation and ablation pattern of seasonal snow cover in Kashmir valley.

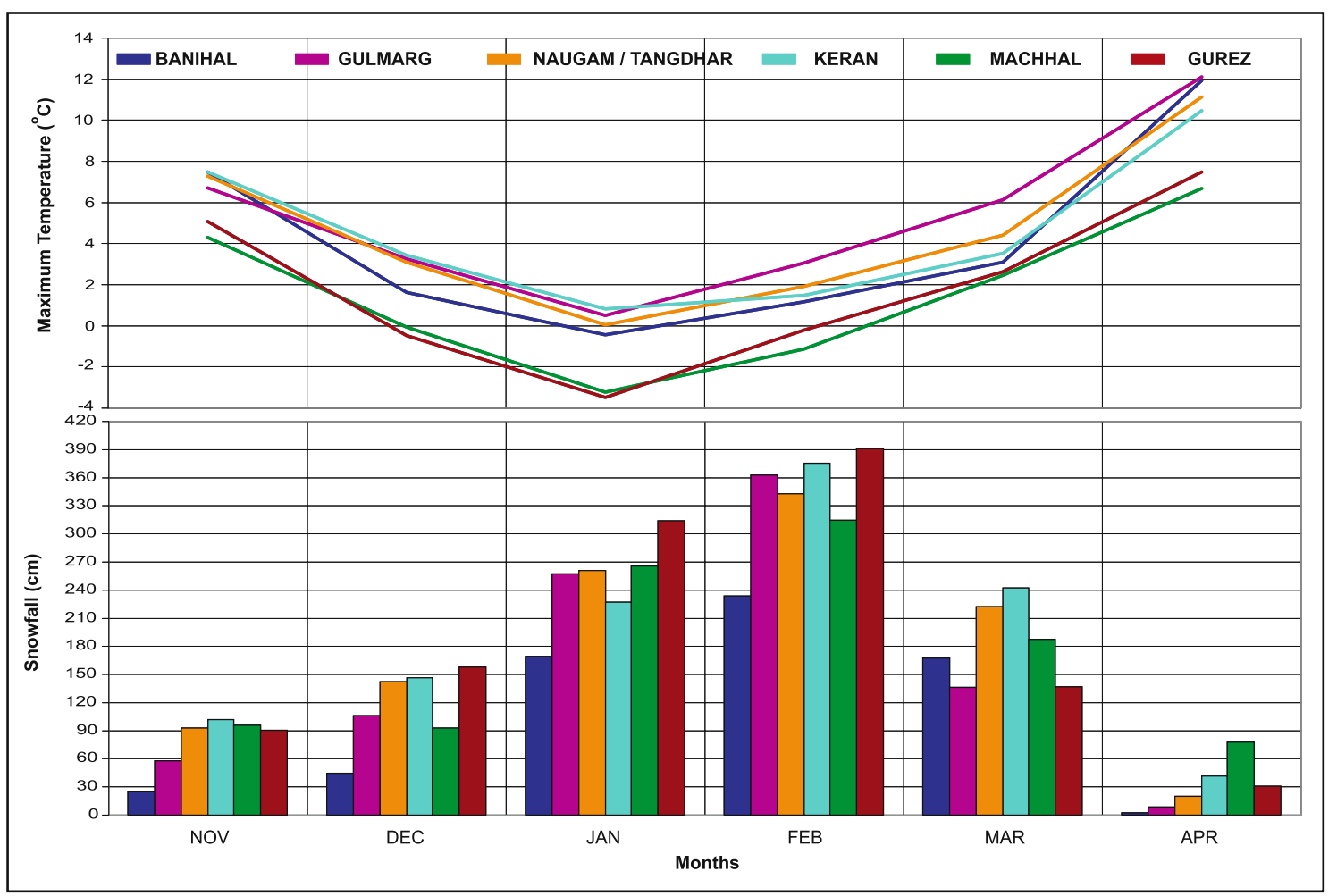

Figure 6. Month-wise average snowfall and average maximum temperature pattern in different regions of Kashmir valley. 
Table 2. Month-wise average snowfall days in different regions of Kashmir valley.

\begin{tabular}{lcccccc}
\hline Month & Banihal & Gulmarg & $\begin{array}{c}\text { Naugam/ } \\
\text { Tangdhar }\end{array}$ & Keran & Machhal & Gurez \\
\hline November & 3 & 4 & 5 & 6 & 6 & 5 \\
December & 4 & 7 & 8 & 7 & 9 & 9 \\
January & 8 & 11 & 12 & 11 & 13 & 15 \\
February & 12 & 14 & 17 & 16 & 17 & 16 \\
March & 9 & 10 & 13 & 13 & 13 & 11 \\
April & 1 & 2 & 3 & 6 & 6 & 4 \\
Total & 37 & 48 & 58 & 59 & 64 & 60 \\
\hline
\end{tabular}

Table 3. Region-wise geographical variables of Kashmir valley.

\begin{tabular}{|c|c|c|c|c|c|c|}
\hline & $\begin{array}{l}\text { Banihal } \\
\text { (\% area) }\end{array}$ & $\begin{array}{l}\text { Gulmarg } \\
(\% \text { area) }\end{array}$ & $\begin{array}{l}\text { Naugam/ } \\
\text { Tangdhar } \\
\text { (\% area) }\end{array}$ & $\begin{array}{l}\text { Keran } \\
(\% \text { area })\end{array}$ & $\begin{array}{l}\text { Machhal } \\
\text { (\% area) }\end{array}$ & $\begin{array}{c}\text { Gurez } \\
(\% \text { area })\end{array}$ \\
\hline \multicolumn{7}{|l|}{ Altitude } \\
\hline$>800 \mathrm{~m} \leq 2000 \mathrm{~m}$ & 74 & 32 & 31 & 19 & 13 & 00 \\
\hline$>2000 \mathrm{~m} \leq 3000 \mathrm{~m}$ & 23 & 41 & 50 & 56 & 52 & 20 \\
\hline$>3000 \mathrm{~m} \leq 4000 \mathrm{~m}$ & 03 & 21 & 18 & 24 & 29 & 57 \\
\hline$>4000 \mathrm{~m} \leq 5200 \mathrm{~m}$ & 00 & 06 & 01 & 02 & 06 & 23 \\
\hline \multicolumn{7}{|l|}{ Slope } \\
\hline$\geq 0^{\circ} \leq 15^{\circ}$ & 71 & 22 & 31 & 15 & 18 & 16 \\
\hline$>15^{\circ} \leq 30^{\circ}$ & 19 & 44 & 35 & 34 & 40 & 43 \\
\hline$>30^{\circ} \leq 55^{\circ}$ & 10 & 33 & 32 & 49 & 40 & 40 \\
\hline$>55^{\circ}$ & 00 & 01 & 02 & 03 & 02 & 01 \\
\hline \multicolumn{7}{|l|}{ Aspect } \\
\hline Northern & 66 & 53 & 62 & 53 & 51 & 51 \\
\hline Southern & 34 & 47 & 38 & 47 & 49 & 49 \\
\hline \multicolumn{7}{|l|}{ Ground cover } \\
\hline Forested & 14 & 74 & 48 & 57 & 46 & 18 \\
\hline Non-forested & 86 & 26 & 52 & 43 & 54 & 82 \\
\hline
\end{tabular}

\subsection{Region-wise evaluation of seasonal snow cover}

Table 3 shows the geographical parameters (altitude, aspect, slope, ground cover and locations) in different regions using GIS maps and the region-wise details.

\subsubsection{Gurez region}

The majority of the area (80\%) in Gurez region lies above $3000 \mathrm{~m}$ with slope range between $15^{\circ}$ and $55^{\circ}$, whereas remaining area is gradual $\left(<15^{\circ}\right)$ and lies between $2000-3000 \mathrm{~m}$. This region has approximately equal proportion of northern and southern aspects and having large non-forested area.

\subsubsection{Machhal region}

Machhal region has $35 \%$ area lies above $3000 \mathrm{~m}$ and $52 \%$ area lies between $2000-3000 \mathrm{~m}$ with majority of the area (80\%) lies between $15^{\circ}$ and $55^{\circ}$ slope. In this region approximately equal proportion of northern and southern aspects has observed and half of the area in Machhal region is non-forested.

\subsubsection{Keran region}

Keran region shows that $56 \%$ area lies between 2000 and $3000 \mathrm{~m}$ and $26 \%$ area lies above $3000 \mathrm{~m}$, however, majority of the area $(83 \%)$ lies between $15^{\circ}$ and $55^{\circ}$ slopes. This region has also approximately equal proportion of northern and southern aspects and half of the area is non-forested.

\subsubsection{Naugam/Tangdhar region}

The half of the area of Naugam/Tangdhar regions lies between 2000 and $3000 \mathrm{~m}$ and $31 \%$ area is gradual and lies below $2000 \mathrm{~m}$. In this region, $67 \%$ area is having slope range between $15^{\circ}$ and $55^{\circ}$. In this 
region larger area is having northern aspect and approximately half of the area is non-forested.

\subsubsection{Gulmarg region}

In Gulmarg region $41 \%$ area lies between 2000 and $3000 \mathrm{~m}$ and $32 \%$ area lies below $2000 \mathrm{~m}$ whereas $77 \%$ area have $15^{\circ}$ to $55^{\circ}$ slope. This region has approximately equal proportion of northern and southern aspects and majority of the area is forested.

\subsubsection{Banihal region}

Banihal region shows that majority of the area (74\%) having gradual slope and below $2000 \mathrm{~m}$ altitude. Only $26 \%$ area lies above $2000 \mathrm{~m}$ and have slope range between $15^{\circ}$ and $55^{\circ}$. Most of the area in this region has northern aspect and non-forested.

It has also been observed from the analysis that all regions have negligible steep slopes $\left(>55^{\circ}\right)$, where slopes remain devoid of snow cover. The above analysis shows that higher altitude and negligible area of steep slopes are favourable in Gurez, Machhal and Keran regions, however ground cover and aspect parameters are not favourable for longer snow cover period. Further, Gurez has higher altitude than Machhal and Keran regions, which supports the longer duration of snow cover than all other regions. Similarly in Banihal region, large area is having favourable aspect for longer snow cover period, but majority of the area is nonforested and lies below $2000 \mathrm{~m}$, may be the cause of advance melting.

Hence, sections 4.2 and 4.3 indicate that all the geographical parameters influence snowfall and temperature pattern but altitude is the major parameter for retaining seasonal snow cover and remaining parameters are secondary. In addition, positions of the regions may also be a deciding factor for retaining seasonal snow cover, as Gurez, Machhal, Keran and Naugam/Tangdhar regions located in Shamshawari range but Gurez and Machhal are closer to greater Himalayan zone than other regions and having longer duration of seasonal snow cover. Similarly Gulmarg and Banihal regions are located in the NW and SE tip of Pir Panjal range $(J \& K)$ respectively which are away from greater Himalayan zone and have short duration of seasonal snow cover.

\section{Conclusions}

The monitoring of seasonal snow cover in different regions of Kashmir valley shows significant changes in accumulation and ablation pattern. The study shows that altitude and positions of different regions are the primary parameters and play an important role in the accumulation as well as ablation pattern of seasonal snow cover. This information can be used for regionalization in lower Himalayan zone for winter sports, tourism, transport, land and water management. Further this type of study can be vital input for climate change but requires long term and continuous monitoring of areal extent of snow cover. The similar study can also be explored for glacier retreat/surging based on the regional differences. The other optical satellite data with high spectral and spatial resolution such as AWiFS or ASTER can be incorporated for continuous long term snow cover monitoring in near future.

\section{Acknowledgements}

Authors are grateful to the Director, Snow and Avalanche Study Establishment (SASE), Chandigarh for constant motivation and support for this study. The authors would also like to thank DEAL (DRDO), Dehradun for providing satellite imageries.

\section{References}

Bahadur J 1993 Precipitation Characteristics over High Himalayas; Proc. of National Symposium on Meteorology and National Development, Mausam Bhawan, New Delhi, India, March 17-19.

Dozier J, Schneider S R and McGinnis Jr D F 1981 Effect of grain size and snow pack water equivalence on visible and near-infrared satellite observations of snow; Water Resour. Res. 17 1213-1221.

Dozier J 1984 Snow reflectance from Landsat-4 thematic mapper; IEEE Transactions on Geoscience and Remote Sensing 22 323-328.

Dozier J 1985 Spectral signatures of snow in visible and near-IR wavelengths; Proceedings of the 3rd International Colloquium on Spectral Signatures of Objects in Remote Sensing, Les Arcs, France, 16-20 December, ESA-SP-247.

Dozier J 1989 Spectral signature of alpine snow cover from the Landsat Thematic Mapper; Remote Sens. Environ. 28 9-22.

Leica Geosystems 2006 ERDAS Imagine Tour Guides; Leica Geosystems Geospatial Imaging, LLC USA 305-310.

Gupta R P, Haritashya U K and Singh P 2005 Mapping dry/wet snow cover in the Indian Himalayas using IRS multispectral imagery; Remote Sens. Environ. 97 458-469.

Hall D K, Riggs G A and Salomonson V V 1995 Development of methods for mapping global snow cover using moderate resolution imaging spectroradiometer data; Remote Sens. Environ. 54 127-140.

Hall D K, Foster J L, Verbyla D L, Klein A G and Benson C S 1998 Assessment of snow-cover mapping accuracy in a variety of vegetation-cover densities in central Alaska; Remote Sens. Environ. 66 129-137. 
Hall D K, Foster J L, Salomonson V V, Klein A G and Chein J Y L 2001 Development of a technique to assess snow-cover mapping errors from space; IEEE Transactions on Geoscience and Remote Sensing 39(2) 432-438.

Hall D K, Riggs G A, Salomonson V V, DiGirolamo N and Bayr K J 2002 MODIS snow cover products; Remote Sens. Environ. 83 181-194.

Konig M, Winther J G and Isaksson E 2001 Measuring snow and glacier properties from satellite; Rev. Geophys. 39 $1-27$.

Kulkarni A V, Randhawa S S, Rathore B P, Bahuguna I M and Sood R K 2002a Snow and Glacier Melt Runoff Model to Estimate Hydropower Potential; J. Indian Soc. Remote Sensing 30(4) 221-228.

Kulkarni A V, Mathur P, Rathore B P, Suja Alex, Thakur N and Manoj 2002b Effect of global warming on snow ablation pattern in the Himalaya; Curr. Sci. 83 120-123.

Kulkarni A V and Rathore B P 2003 Snow cover monitoring in Baspa basin using IRS WiFS data; Mausam 54 335-340.

Kulkarni AV, Singh S K, Mathur P and Mishra V D 2006 Algorithm to monitor snow cover using AWiFS data of RESOURCESAT-1 for the Himalayan region; Int. J. Remote Sensing 27(12) 2449-2457.

McClung D and Schaerer P 2006 The avalanche handbook; Publ. The Mountaineers Book 3 111-115.

Negi H S, Mishra V D and Mathur P 2005a Change Detection Study for Snow Cover Mountains using Remote Sensing and Ground Based Measurements; J. Indian Soc. Remote Sensing 33(2) 245-251.

Negi H S, Thakur N K and Sharma J K 2005b Snowcover Monitoring using Remote Sensing in NWHimalaya; Workshop on Integrated Management of Natural Resources in Mountains, Pantnagar, India, November 28-December 02.

Negi H S, Snehmani and Thakur N K 2008 Operational Snow Cover Monitoring in NW-Himalaya using Terra and
Aqua MODIS Imageries; Proc. of International Workshop on Snow, Ice, Glacier and Avalanches, IIT Bombay, India, January 7-9.

Negi H S, Kulkarni A V and Semwal B S 2009 Estimation of Snowcover Distribution in Beas basin, Indian Himalaya using Satellite Data and Ground Measurements; J. Earth Syst. Sci. 118(5) 525-538.

O'brian H W and Munis H 1975 Red and Near-Infrared spectral reflectance of snow; U.S.A. CRREL Research Report 332 18p.

Rango A and Martinec J 1995 Revisiting the degree day method for snowmelt computation; Water Res. Bull. 31(4) 657-669.

Rango A 1996 Space borne remote sensing for snow hydrology applications; Hydrol. Sci. 41 477-497.

Racoviteanu A E, Williams M W and Barry R G 2008 Optical Remote Sensing of Glacier Characteristics: A Review with Focus on the Himalaya; Sensors 8 3355-3383.

Singh P and Kumar N 1997 Effect of orography on precipitation in western Himalayan region; J. Hydrol. 199 183-206.

Singh P, Kumar N and Arora M 2000 Degree day factors for snow and ice for Dokriani Glacier Garhwal Himalayas; J. Hydrol. 235(1-2) 1-11.

Sharma S S and Ganju A 2000 Complexities of avalanche forecasting in Western Himalaya - An overview; Cold Regions Science and Technology 31 95-102.

Shekhar M S, Chand H, Kumar S, Srinivasan K and Ganju A 2009 Climate change studies over Western Himalaya; International Symposium on Snow and Avalanches, Manali, India, April 6-10; Annals of Glacio$\operatorname{logy}$ (in press).

Wiscombe W J and Warren S G 1980 A model for the spectral Albedo of snow-I: Pure snow; J. Atmos. Sci. 37 $2712-2733$.

Warren S G 1982 Optical Properties of Snow; Reviews of Geophysics and Space Physics 20(1) 67-89. 